\title{
Effect of Chitosan Supplemented Diet on Survival, Growth, Feed Utilization, Body Composition \& Histology of Sea Bass (Dicentrarchus labrax)
}

\author{
M. A. Zaki' ${ }^{1}$, M. El-S. Salem², M. M. Gaber ${ }^{3 *}$, A. M. Nour ${ }^{1}$ \\ ${ }^{1}$ Departments of Animal and Fish Production, Faculty of Agriculture, Alexandria University, El Shatby, Egypt \\ ${ }^{2}$ National Institute of Oceanography and Fisheries, Alexandria, Egypt \\ ${ }^{3}$ National Institute of Oceanography and Fisheries, Cairo, Egypt \\ Email: "gabermagdy@yahoo.com
}

Received 9 September 2015; accepted 10 December 2015; published 17 December 2015

\section{Abstract}

The effect of chitosan incorporated into feed formulation on the growth, feed utilization, body composition and histological response of sea bass (Dicentrarchus labrax) was investigated. Final fish weight, feed conversion ratio (FCR), specific growth rate (SGR), protein efficiency ratio (PER), protein productive value (PPV), and energy utilization (EU) of sea bass feed chitosan supplemented diet and the control diet were determined at the end of experiment. Data presents mean \pm SD from triplicate determination $(n=3)$ for 75 days feeding trial. Different concentrations $(0.5,1.0$, 2.0, $3.0 \& 4.0$ ) and control without chitosan incorporated with total fish feed in the form of dry diets were fed for 75 days. Average final weight (FW) was significantly higher at diet $3\left(1 \mathrm{~g} \cdot \mathrm{kg}^{-1} \mathrm{chi}^{-}\right.$ tosan) and the lowest in control fish group, specific growth rate (SGR) was significant at diet 3. Also, protein efficiency ratio (PER), protein productive value (PPV), and energy utilization (EU) showed the same trend. The chemical body composition, crude protein, dry matter, crude fat and ash were significant $(P \leq 0.01)$ different compared to control groups. The present investigation suggested that the chitosan incorporated into diets of sea bass fish certainly enhanced the non specific responses and reduced mortality and also improved the growth performance of fish.

\section{Keywords}

Sea Bass, Chitosan, Growth Performance, Body Composition, Intestine Histology

\section{Introduction}

Fish farming is acknowledged as an important and substantial part of the global fishing industry. The aquaculture industry in Egypt has been developed and well sustained within the last few decades. Accordingly, aqua-

\footnotetext{
${ }^{*}$ Corresponding author.
} 
culture production has continued on an upward trend to reach 1,385,804 tons in 2012 [1]. Among the marineculture commodities, the sea bass is the most popular fish species, production of which in the Egyptian aquaculture industry has increased exponentially from 15,228 tons from 2000 to 2012. The development of environmental-friendly technologies to improve the quality of aquaculture fish production is broadly accepted. Therefore, attempts have been made to develop fish feeding pellets that generate less water pollution and improve the health of fish.

Chitosan, a deacetylated chitin, is widespread in nature. The exoskeletons of arthropods such as crabs, shrimps, insects, and other marine creatures in the crustacean family are good sources of chitosan [2]-[4]. Chitosan is a natural alkaline polysaccharide with positive charges, and also one of the most abundant natural polymers [5]-[7]. As a nontoxic, biodegradable carbohydrate polymer [8] it contains amino and hydroxyl groups per residue [9] which gives chitosan many biological activities, such as haemostatic [10], anti-inflammatory [11], antitumor activity [12] [13], antimicrobial activity [15], hypoglycemic and hypo cholesterolemic activity [16] [17] and an immune-stimulatory effect [18] [19].

Chitosan has become a new candidate as a growth-promoter for farm animals. Previous experiments involving piglets and broilers have demonstrated that chitosan improves growth performance of animals [20]-[23]. But the mechanism was not understood completely.

The effect of dietary chitosan on fish growth has not received much attention. The present study was performed to gather information on the effects of dietary chitosan on the growth, feed efficiency and survival of sea bass.

\section{Material and Methods}

\subsection{Experimental Diets}

Formulation and proximate composition of the experimental diets are presented in Table 1 (Chitosan was obtained from National Institute of Oceanography and Fisheries Alexandria) was included in the diet at (0.5, 1.0, 2.0, $3.0 \& 4.0 \mathrm{~g} \cdot \mathrm{kg} \mathrm{diet}^{-1}$ ) and control without chiotosan based on the best results obtained before, in terms of growth performance, feed utilization and survival. All the dry ingredients were mixed thoroughly. Fish oil, vitamin and mineral mixture and chitosan were separately mixed and gradually added to dry mixture. The other materials were finely ground in a house blender and used in the formulation of six experimental diets isonitrogenous $\left(451 \mathrm{~g} \cdot \mathrm{kg}^{-1}\right)$ and isocaloric $\left(49.5 \mathrm{kcalg}^{-1}\right)$. The experiment was designed in a one way design. Different concentration $0.5,1.0,2.0,3.0 \& 4.0 \mathrm{~g} \cdot \mathrm{kg} \mathrm{diet}^{-1}$ of chitosan and control without chitosan are incorporated with total fish feed in the form of dry diets for 75 days as described in Table 1 . Warm distilled water $\left(45^{\circ} \mathrm{C}\right)$ which was slowly added until the diets began to clump. Diets were processed by a mincer with die into $3 \mathrm{~mm}$ diameter, spaghetti-like strands, sun- dried and stored in air tight containers. The experimental fish were fed the test diets for tow week as adaptation period to adapt them to these test diets. After the adaptation period was completed, fish in each aquarium were reweighed, and their initial weights were recorded. Fish in each aquarium were fed twice daily (six days a week) at a rate of $15 \%$ of body weight for the first 30 days then decreased to $12 \%$ for 15 days then to $10 \%$ and $8 \%$ for the rest of experimental period. The experimental work of the present study was carried out at the Department of Fish Nutrition, National Institute of Oceanography \& Fisheries Alexandria Branch, Egypt. The dried pellets were then broken into small pieces, packed in airtight polythene bags and stored in a refrigerator until feeding. The required quantity of the diets were thawed and mechanically broken into small particles and then fed to fishes.

\subsection{Culture Condition}

Sea bass (Dicentrarchus labrax) fry obtained from Fish Hatchery, National Institute of Oceanography \& Fisheries Alexandria Branch, Egypt were used in the present study. Fish were placed randomly in fifty four glass aquaria with dimensions of $100 \times 40 \times 40 \mathrm{~cm}$ and $120 \mathrm{~L}$ capacity of sea water per aquarium, three replicates per treatment were used in this study. Each aquarium stocked with twenty fry of Sea bass with an average initial body weight of $0.21 \pm 0.01 \mathrm{~g}$ fish. Each aquarium was cleaned daily in order to prevent accumulation of fecal materials and reduce the growth of algae, and the same amount of fresh sea water was used to refill the aquaria. Water was partially changed once every three days using fresh sea water. Aeration was continuously provided using an air blower. 
Table 1. Composition of a diet similar to a high quality commercial sea bass diet and experimental diets supplemented with various percentage of Chitosan feed to fry.

\begin{tabular}{|c|c|c|c|c|c|c|}
\hline \multirow{2}{*}{ Ingredients (\%) } & \multicolumn{6}{|c|}{ Diets } \\
\hline & 1 & 2 & 3 & 4 & 5 & 6 \\
\hline Fish meal (C.P.70\%) & 50.0 & 50.0 & 50.0 & 50.0 & 50.0 & 50.0 \\
\hline Soybean meal (C.P.44\%) & 19.0 & 19.0 & 19.0 & 19.0 & 19.0 & 19.0 \\
\hline Yellow corn meal & 7.0 & 7.0 & 7.0 & 7.0 & 7.0 & 7.0 \\
\hline Rice bran & 11.7 & 11.7 & 11.7 & 11.7 & 11.7 & 11.7 \\
\hline Fish oil & 3.0 & 3.0 & 3.0 & 3.0 & 3.0 & 3.0 \\
\hline Sunflower oil & 3.0 & 3.0 & 3.0 & 3.0 & 3.0 & 3.0 \\
\hline Vit. \& Min premix ${ }^{1}$ & 2.0 & 2.0 & 2.0 & 2.0 & 2.0 & 2.0 \\
\hline Calcium diphosphate & 1.0 & 1.0 & 1.0 & 1.0 & 1.0 & 1.0 \\
\hline Molasses $^{2}$ & 2.0 & 2.0 & 2.0 & 2.0 & 2.0 & 2.0 \\
\hline Colin & 0.2 & 0.2 & 0.2 & 0.2 & 0.2 & 0.2 \\
\hline Vitamin C & 0.3 & 0.3 & 0.3 & 0.3 & 0.3 & 0.3 \\
\hline Lysine & 0.3 & 0.3 & 0.3 & 0.3 & 0.3 & 0.3 \\
\hline Methionine & 0.3 & 0.3 & 0.3 & 0.3 & 0.3 & 0.3 \\
\hline Antitoxins & 0.1 & 0.1 & 0.1 & 0.1 & 0.1 & 0.1 \\
\hline Enzymes & 0.1 & 0.1 & 0.1 & 0.1 & 0.1 & 0.1 \\
\hline Chitosan (g/kg) & --- & 0.5 & 1 & 2 & 3 & 4 \\
\hline \multicolumn{7}{|l|}{ Proximate analyses $(\%)^{3}$} \\
\hline Dry matter & 93.5 & 93.2 & 95.4 & 92.3 & 92.3 & 96.4 \\
\hline Crude protein & 45.1 & 45.1 & 45.1 & 45.1 & 45.2 & 45.1 \\
\hline Crude fat & 10.9 & 10.9 & 10.9 & 10.7 & 10.5 & 10.6 \\
\hline Ash & 10.2 & 10.4 & 10.1 & 10.4 & 10.4 & 10.0 \\
\hline Crude fiber & 3.3 & 3.4 & 3.5 & 3.8 & 3.8 & 4.1 \\
\hline $\mathrm{NFE}^{4}$ & 30.5 & 30.1 & 30.4 & 30.0 & 30.1 & 30.2 \\
\hline Gross energy Kcal & 496.4 & 495.2 & 496.8 & 494.8 & 493.6 & 495.6 \\
\hline N:C ratio (mg cp:kcal) & 90.1 & 91.1 & 90.8 & 91.1 & 91.6 & 91.0 \\
\hline
\end{tabular}

${ }^{1}$ Vitamin and mineral premixed according to [44]. ${ }^{2}$ Molasses was used as a binder and attractant according to [45]. ${ }^{3}$ Values represent the mean of three sample replicates. ${ }^{4} \mathrm{NFE}=100-(\%$ protein $+\%$ fat $+\%$ fiber $+\%$ ash $)$

\subsection{Analyses}

The proximate composition and gross energy content of the diets were ascertained. Dry matter, crude protein, crude fat, crude fiber, ash and nitrogen free extract (NFE) were analyzed according to [24].

At the end of 75 days of growth study, fish per tank were collected for analysis. Fish were homogenized for whole body analysis and frozen at $-18^{\circ} \mathrm{C}$. The homogenized samples were oven dried at $100^{\circ} \mathrm{C}$ for $24 \mathrm{hrs}$. Chemical analyses of whole body, Moisture protein, lipid, and ash were performed according to standard [24] methods and gross energy (Ballistic bomb calorimeter, Gallenhamp, England).

All fish were sacrificed to obtain intestine. Intestine were fixed in Bouin's solution [25] for 24 hours and then transferred to alcohol (70\%). After conventional histological processing, sections (5 - $7 \mu \mathrm{m}$ thick) were stained with haematoxylin and eosin and observed under a light microscope (Leica DM500). Assessment of gonad development followed the description of [26].

\subsection{Water Quality}

Water quality parameters (temperature, dissolved oxygen, $\mathrm{pH}$, ammonia, nitrate and nitrite) were monitored to ensure water quality remained well within limits recommended for Sea bass. Water temperature and dissolved oxygen were measured every other day using an YSI Model 58 oxygen meter (Yellow Springs Instruments, Yellow Springs, OH). Ammonia and nitrite were measured at wkly intervals using the titration methods of Golterman; [27] $\mathrm{pH}$ was monitored twice weekly using an electronic $\mathrm{pH}$ meter $(\mathrm{pH}$ pen Fisher Scientific, Cincinnati, $\mathrm{OH})$. During the feeding trial, the water quality parameter averaged $( \pm \mathrm{SD})$ : water temperature $27.8^{\circ} \mathrm{C} \pm 0.8^{\circ} \mathrm{C}$ dissolved oxygen $4.8 \pm 0.4 \mathrm{mgl}^{-1}$; $\mathrm{pH} 7.4 \pm 0.6$; ammonia $\pm 0.04 \mathrm{mgl}^{-1}$; nitrite $0.1 \pm 0.05 \mathrm{mgl}^{-1}$; nitrate $1.5 \pm 0.2$ 
$\mathrm{mgl}^{-1}$; Salinity $35.4 \pm 1.6 \mathrm{gl}^{-1}$.

\subsection{Growth Parameters and Statistical Analysis}

Calculations of growth parameters were conducted according [28]. Data were analyzed by analysis of variance (ANOVA) using the SAS ANOVA procedure [29] Duncan's multiple range tests were used to compare differences among individual means. Treatment effects were considered significant at $\mathrm{P}<0.05$. All percentages and ratio were transformed to arcsine values prior to analysis [30].

\section{Results}

\subsection{Growth Performance}

The results of means final body weight (FBW), specific growth rate (SGR), gain weight (GW), relative growth rate (RGR) and survival rate are presented in Table 2. At the start of the experiment, there were no significant differences $(P \leq 0.05)$ in average initial body weight, which indicates that there was homogeneity among these groups. At the end of the experiment, the average FBW and SGR (\% per day) showed that the groups of fish fed diet 3 supplement with $1 \mathrm{~g} \cdot \mathrm{kg} \mathrm{diet}^{-1}$ chitosan significantly $(\mathrm{P} \leq 0.05)$ higher values of FBW (Figure 1 \& Figure 2) and also, SGR compared with groups of fish fed control diet 1 (without chitosan) and other-based diets (2, 4 $6 \mathrm{~g} \cdot \mathrm{kg} \operatorname{diet}^{-1}$ chitosan) respectively. Among diets containing chitosan, the response of fish to increasing levels of dietary chitosan was linear. At the higher levels of dietary chitosan (above $1 \mathrm{~g} \cdot \mathrm{kg} \mathrm{diet}^{-1}$ ), there were no linear increase in FBW and SGR.

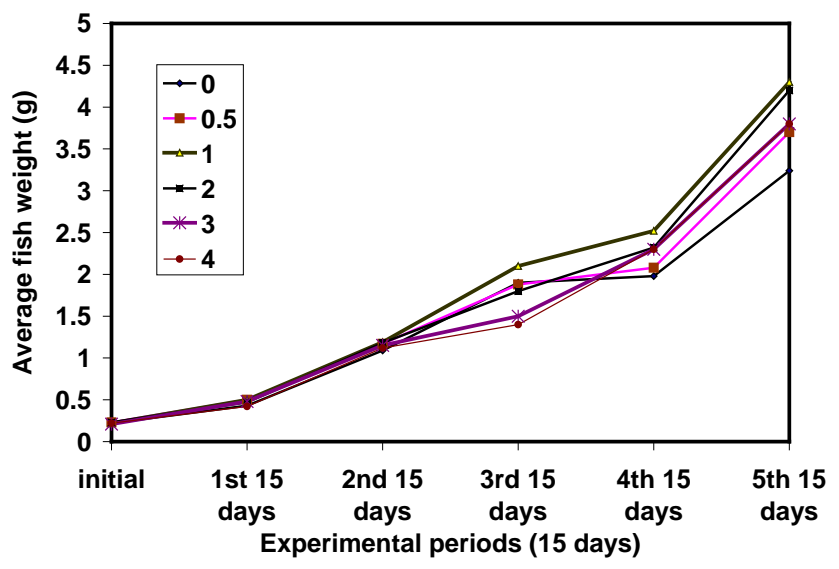

Figure 1. Effects of Chitosan on growth rate of sea bass.

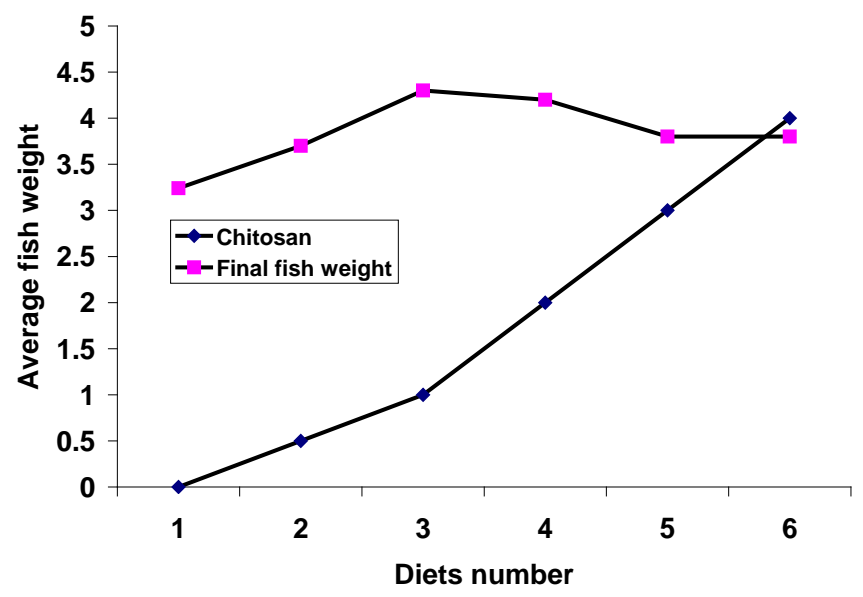

Figure 2. Effects of Chitosan on final weight of sea bass. 


\subsection{Feed Utilization Efficiency}

The effect of dietary treatments on feed utilization of sea bass fry were shown on Table 3 . The fish that fed on the diets 3 showed significantly the highest feed intake ratio (FI, g/fish) compared to fish fed on the diet 6 which had significantly the lowest FI value. Groups of fish fed diet $3 \& 4$ (1 \& $2 \mathrm{~g} \cdot \mathrm{kg} \mathrm{diet}^{-1}$ chitosan) had significantly $(\mathrm{P} \leq 0.05)$ the best values for FCR, PER. The poorest results were recorded with groups of fish fed diet $1 \& 2(0$ \& $0.5 \mathrm{~g} \cdot \mathrm{kg}$ diet $^{-1}$ chitosan). Protein productive value (PPV) was significantly $(\mathrm{P} \leq 0.5)$ differences between fish fed on control and supplemental diets, but generally improved PPV was observed in sea bass fed on diet 3 supplemented with $1.0 \mathrm{~g} \cdot \mathrm{kg}^{-1}$ chitosan followed with fish fed diet $4\left(2.0 \mathrm{~g} \cdot \mathrm{kg}^{-1}\right.$ chitosan). For energy gain (kcal) and energy utilization values, recorded the same trend of PPV.

\subsection{Proximate Composition of Whole Fish}

Chemical compositions of whole fish at the end of the duration of the experiment are shown in Table 4 results demonstrate that whole-body moisture, crude protein, crude fat and energy content were significantly influenced by chitosan supplementation. The results of whole-body proximate analysis, expressed on a wet basis \%, for sea bass fed experimental diets averaged ( $\pm \mathrm{SD}$ ): dry mater, $29.2 \pm 1.9$; crude protein, $16.3 \pm 1.1$; crude fat, $5.3 \pm 0.5$; energy content $487.3 \pm 10.5 \mathrm{kcal}\left(100 \mathrm{~g}^{-1}\right)$; crude ash $5.9 \pm 0.8$. There was a significant $(\mathrm{P} \leq 0.05)$ change in ash content associated with diets supplemented with different levels of chitosan.

A general tendency of increased crude protein was observed in all treatments evident by increasing growth rate and age. This increase was remarkably were higher in fish fed on diet 3 , followed by fish fed on diet 4 , and

Table 2. Effects of Chitosan on growth performances of Sea bass fed control diet and the experimental diets 2 - 6 supplemented with various levels of Chitosan.

\begin{tabular}{|c|c|c|c|c|c|c|c|}
\hline \multirow[b]{2}{*}{ Diets } & \multicolumn{2}{|c|}{ Average (g/fish) } & \multirow[b]{2}{*}{ Gain (g/fish) } & \multirow{2}{*}{$\begin{array}{c}\text { ADG } \\
\text { (g/fish/day) }\end{array}$} & \multirow[b]{2}{*}{ SGR (\%/day) } & \multirow[b]{2}{*}{ RGR (\%) } & \multirow[b]{2}{*}{ Survival (\%) } \\
\hline & Initial & Final & & & & & \\
\hline 1 & $0.22 \pm 0.01$ & $3.24 \pm 0.3 c$ & $3.04 \pm 0.3 \mathrm{~d}$ & $0.04 \pm 0.01 \mathrm{c}$ & $3.73 \pm 0.14 c$ & $1544.3 \pm 62.0 \mathrm{~d}$ & $90.0 \pm 5.0 \mathrm{~b}$ \\
\hline 2 & $0.23 \pm 0.23$ & $3.7 \pm 0.1 b$ & $3.47 \pm 0.1 \mathrm{c}$ & $0.05 \pm 0.01 \mathrm{~b}$ & $3.71 \pm 0.02 c$ & $1609.5 \pm 28.5 \mathrm{~d}$ & $93.0 \pm 2.9 b$ \\
\hline 3 & $0.22 \pm 0.01$ & $4.3 \pm 0.2 \mathrm{a}$ & $4.12 \pm 0.2 \mathrm{a}$ & $0.06 \pm 0.02 \mathrm{a}$ & $3.98 \pm 0.03 a$ & $1985.3 \pm 53.8 \mathrm{a}$ & $100.0 \pm 0.0 \mathrm{a}$ \\
\hline 4 & $0.23 \pm 0.01$ & $4.2 \pm 0.1 \mathrm{a}$ & $3.97 \pm 0.1 \mathrm{a}$ & $0.05 \pm 0.01 b$ & $3.87 \pm 0.05 a$ & $1827.7 \pm 67.4 \mathrm{bc}$ & $93.33 \pm 2.9 b$ \\
\hline 5 & $0.21 \pm 0.01$ & $3.8 \pm 0.6 a b$ & $3.82 \pm 0.3 \mathrm{ab}$ & $0.05 \pm 0.01 \mathrm{~b}$ & $3.92 \pm 0.05 a$ & $1889.6 \pm 73.7 \mathrm{ab}$ & $86.67 \pm 2.9 \mathrm{c}$ \\
\hline 6 & $0.22 \pm 0.01$ & $3.8 \pm 0.1 \mathrm{a}$ & $3.71 \pm 0.2 \mathrm{~b}$ & $0.05 \pm 0.01 \mathrm{~b}$ & $3.78 \pm 0.05 b$ & $1702.2 \pm 62.8 \mathrm{c}$ & $85.0 \pm 0.0 \mathrm{c}$ \\
\hline $\mathrm{F}$ & 1.7 & $5.16^{* *}$ & $10.3^{* *}$ & $11.13^{* *}$ & $10.9^{* *}$ & $11.91^{* *}$ & $10.57^{* *}$ \\
\hline M.S. & & 0.084 & 0.0436 & 0.000007 & 0.0047 & 292 & 8.33 \\
\hline
\end{tabular}

${ }^{1}$ Values are mean \pm standard deviation. Values in the same column with same superscripts are not significantly different. IBW, initial body weight. FBW, final body weight. SGR (\% per day), specific growth rate = (ln FBW/ln IBW)/time days /75).

Table 3. Effects of Chitosan on feed utilization of Sea bass fed control diet and the experimental diets 2-6 supplemented with various levels of Chitosan.

\begin{tabular}{ccccccc}
\hline Diets & $\begin{array}{c}\text { Feed intake } \\
\text { g/fish }\end{array}$ & FCR & PER & PPV\% & $\begin{array}{c}\text { Energy gain } \\
\text { (kcal) }\end{array}$ & $\begin{array}{c}\text { Energy } \\
\text { utilization }\end{array}$ \\
\hline 1 & $7.82 \pm 0.06 \mathrm{~d}$ & $2.6 \pm 0.29 \mathrm{a}$ & $0.86 \pm 0.1 \mathrm{~d}$ & $15.5 \pm 1.9 \mathrm{~b}$ & $5.17 \pm 0.6 \mathrm{~b}$ & $12.8 \pm 1.4$ \\
2 & $8.03 \pm 0.1 \mathrm{~b}$ & $2.3 \pm 0.04 \mathrm{~b}$ & $0.96 \pm 0.02 \mathrm{c}$ & $16.8 \pm 0.7 \mathrm{ab}$ & $5.26 \pm 0.2 \mathrm{~b}$ & $13.6 \pm 0.4$ \\
3 & $8.53 \pm 0.45 \mathrm{a}$ & $2.1 \pm 0.05 \mathrm{~b}$ & $1.06 \pm 0.03 \mathrm{a}$ & $17.4 \pm 0.8 \mathrm{a}$ & $5.67 \pm 0.5 \mathrm{a}$ & $13.8 \pm 0.8$ \\
4 & $8.23 \pm 0.09 \mathrm{a}$ & $2.1 \pm 0.05 \mathrm{~b}$ & $1.07 \pm 0.03 \mathrm{a}$ & $17.1 \pm 0.6 \mathrm{a}$ & $5.4 \pm 0.1 \mathrm{ab}$ & $13.7 \pm 0.2$ \\
5 & $8.36 \pm 0.16 \mathrm{a}$ & $2.2 \pm 0.1 \mathrm{~b}$ & $1.01 \pm 0.05 \mathrm{~b}$ & $17.3 \pm 0.2 \mathrm{a}$ & $5.92 \pm 0.3 \mathrm{a}$ & $14.8 \pm 0.7$ \\
6 & $7.55 \pm 0.07 \mathrm{c}$ & $2.1 \pm 0.05 \mathrm{~b}$ & $1.05 \pm 0.02 \mathrm{a}$ & $15.5 \pm 0.7 \mathrm{~b}$ & $4.74 \pm 0.2 \mathrm{c}$ & $13.2 \pm 0.6$ \\
$\mathrm{~F}$ & $9.42^{* *}$ & $7.42^{* *}$ & $8.5^{* *}$ & 2.46 & $3.68^{* *}$ & 2.31 \\
$\mathrm{~S}$ & 0.0421 & 0.0175 & 0.0023 & 0.949 & 0.135 & NS \\
\hline
\end{tabular}

${ }^{1}$ Values are mean \pm standard deviation. ${ }^{*}=(\mathrm{P} \leq 0.05){ }^{* *}=(\mathrm{P} \leq 0.01)$. Values in the same column with same superscripts are not significantly different. FCR, feed conversion ratio $=$ dry feed fed/body weight gain. FER $=$ feed efficiency ratio. PER = protein efficiency ratio. 
fish fed on diet 5 \& 6 and control diets had the lowest crude protein content. Similarly, results for dry mater percentage decreased with increasing levels of chitosan then dry matter increased at diet 6 containing $4 \mathrm{~g} \cdot \mathrm{kg}^{-1}$ chitosan. Fat decrease with increasing chitosan level and reach higher level of fish fed on diet 5 contain $3 \mathrm{~g} \cdot \mathrm{kg}^{-1}$ chitosan. Ash content showed the same trend of protein and fat content. Energy content increased with increasing chitosan levels and reach maximum at diet 4 ( $2 \mathrm{~g} \cdot \mathrm{kg}^{-1}$ chitosan).

\subsection{Histological Analysis}

At the end of the experiment, the microscopic structure of sea bass intestines as affected by different levels of chitosan supplement is shown in Table 5 \& Figure 3 is represented for fish groups fed on diets 1 - 6 and appeared in the fish group fed on diets $3 \& 4$ (developed Microvillus). Those different stages of villus maturity as a result effect of various levels of chitosan which reach maximum maturity (developed stage) when fish were fed on diet 3, supplemented with $1 \mathrm{~g} \cdot \mathrm{kg}^{-1}$ chitosan.

Dietary chitosan quadratically increased the ratio of villus height to crypt depth in duodenum on $\mathrm{d} 1.4$ ( $\mathrm{P}<$ $0.05)$ and $2.8(\mathrm{P}<0.01)$, meanwhile, quadratically decreased $(\mathrm{P}<0.01)$ crypt depth in duodenum on $\mathrm{d} 2.8$. Diets supplemented with increasing levels of chitosan increased quadratically the villus height of jejunum on $\mathrm{d} 1.4(\mathrm{P}=$ $0.089)$ and $2.8(\mathrm{P}=0.074)$, and the ratio of villus height to crypt depth on $\mathrm{d} 1.4(\mathrm{P}=0.055)$ and $2.8(\mathrm{P}<0.01)$, however, decreased linearly $(\mathrm{P}<0.05)$ or quadratically $(\mathrm{P}<0.01)$ the crypt depth on $\mathrm{d} 2.8$. In addition, dietary chitosan quadratically increased the villus height and the ratio of villus height to crypt depth in ileum on $\mathrm{d} 1.4$ ( $\mathrm{P}<$ $0.01, \mathrm{P}<0.01)$ and $2.8(\mathrm{P}<0.01, \mathrm{P}<0.01)$, however, linearly $(\mathrm{P}<0.05)$ and quadratically $(\mathrm{P}<0.05)$ decreased crypt depth on $\mathrm{d} 1.4$ and quadratically $(\mathrm{P}<0.05)$ decreased crypt depth on $\mathrm{d} 2.8$.

Table 4. Initial and final whole body composition (wet weight basis) of Sea bass fed control diet and 2-6 diets supplemented with Chitosan as feed attractant.

\begin{tabular}{cccccc}
\hline Diets & Dry matter & Crude protein & Crude fat & Ash & Gross energy(kcal) \\
\hline 1 & $32.2 \pm 0.2 \mathrm{a}$ & $14.57 \pm 0.1 \mathrm{~d}$ & $5.86 \pm 0.08 \mathrm{a}$ & $6.71 \pm 0.1 \mathrm{a}$ & $475.3 \pm 5.9 \mathrm{c}$ \\
2 & $30.3 \pm 0.5 \mathrm{~b}$ & $17.05 \pm 0.5 \mathrm{a}$ & $5.41 \pm 0.16 \mathrm{~b}$ & $6.21 \pm 0.14 \mathrm{~b}$ & $488.6 \pm 0.3 \mathrm{ab}$ \\
3 & $27.2 \pm 1.0 \mathrm{c}$ & $17.51 \pm 0.3 \mathrm{a}$ & $4.77 \pm 0.17 \mathrm{c}$ & $5.4 \pm 0.11 \mathrm{c}$ & $498.6 \pm 0.9 \mathrm{a}$ \\
4 & $27.8 \pm 0.5 \mathrm{c}$ & $16.92 \pm 0.4 \mathrm{ab}$ & $4.74 \pm 0.15 \mathrm{c}$ & $6.72 \pm 0.15 \mathrm{a}$ & $477.9 \pm 11.1 \mathrm{c}$ \\
5 & $30.2 \pm 1.1 \mathrm{~b}$ & $16.05 \pm 0.6 \mathrm{~b}$ & $5.87 \pm 0.19 \mathrm{a}$ & $5,59 \pm 0.43 \mathrm{c}$ & $500.3 \pm 14.9 \mathrm{a}$ \\
6 & $27.6 \pm 1.2 \mathrm{c}$ & $15.63 \pm 0.2 \mathrm{c}$ & $5.16 \pm 0.1 \mathrm{~b}$ & $4.6 \pm 0.14 \mathrm{~d}$ & $483.2 \pm 7.5 \mathrm{~b}$ \\
$\mathrm{~F}$ & $18.0^{* *}$ & $22.66^{* *}$ & $35.89^{* *}$ & $47.18^{* *}$ & 4.53 \\
\hline
\end{tabular}

Means in the same row bearing different superscripts differ significantly at 0.05 levels. Values are means \pm SD ( $N=3$ for whole wet body composition). initial whole body composition were as follows: dry matter $20.56 \pm 0.4$, crude protein $10.12 \pm 0.1$, crude fat $2.2 \pm 0.1$, ash $3.9 \pm 0.01$, and gross energy $105.48 \pm 1.51 \mathrm{kcal} / 100 \mathrm{~g}$.

Table 5. Microvilli structure in terms of length of posterior gut of Sea bass fed on diets supplemented with Chitosan.

\begin{tabular}{ccccc}
\hline \multirow{2}{*}{ Diets } & \multicolumn{4}{c}{ Microvilli length $(\mu \mathrm{m})$} \\
\cline { 2 - 5 } & Max length & Min length & Mean & Angle \\
\hline 1 (control) & $155.10 \pm 12.2 \mathrm{c}$ & $51.63 \pm 5.30 \mathrm{c}$ & $103.36 \pm 8.75 \mathrm{c}$ & $-3.48 \pm 4.5 \mathrm{~d}$ \\
$2(0.5)$ & $205.40 \pm 16.2 \mathrm{~b}$ & $85.51 \pm 6.10 \mathrm{c}$ & $145.46 \pm 11.15 \mathrm{~b}$ & $0.57 \pm 3.8 \mathrm{~d}$ \\
$3(1.0)$ & $251.91 \pm 12.4 \mathrm{a}$ & $97.51 \pm 7.2 \mathrm{~b}$ & $174.71 \pm 14.1 \mathrm{a}$ & $12.4 \pm 6.1 \mathrm{c}$ \\
$4(2.0)$ & $251.96 \pm 10.3 \mathrm{a}$ & $101.17 \pm 6.5 \mathrm{ab}$ & $176.57 \pm 12.9 \mathrm{a}$ & $92.14 \pm 5.2 \mathrm{a}$ \\
$5(3.0)$ & $254.11 \pm 13.4 \mathrm{a}$ & $110.24 \pm 5.90 \mathrm{a}$ & $182.18 \pm 13.6 \mathrm{a}$ & $27.9 \pm 7.1 \mathrm{~b}$ \\
$6(4.0)$ & $273.16 \pm 17.5 \mathrm{a}$ & $91.93 \pm 7.10 \mathrm{bc}$ & $182.54 \pm 15.1 \mathrm{a}$ & $10.68 \pm 2.0 \mathrm{c}$ \\
F & $29.87^{* *}$ & $30.70^{* *}$ & $18.04^{* *}$ & $149.45^{* *}$ \\
MS & 193 & 40.08 & 163 & 25.2 \\
\hline
\end{tabular}

Different letters within a line denotes significant differences $(\mathrm{P}<0.05)$. Values expressed in mean \pm SD. 


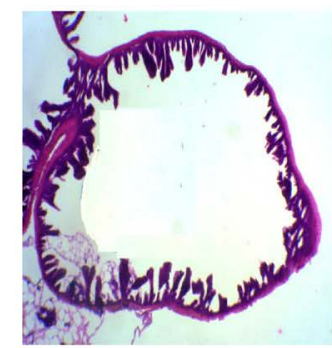

Diet 1 Control $(\times 10)$

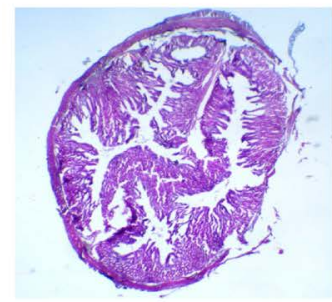

$\operatorname{Diet}(3) 1.0(\times 10)$

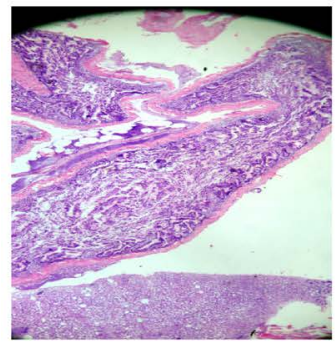

Diet (5) $3.0(\times 10)$

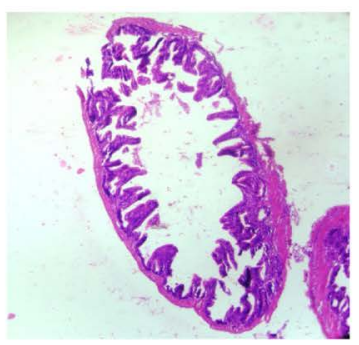

Diet (2) $0.5(\times 10)$

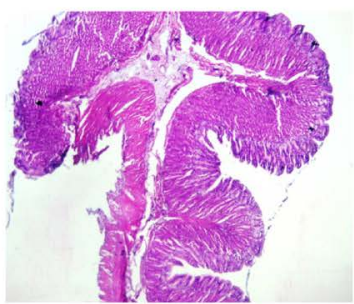

Diet (4) $2.0(\times 10)$

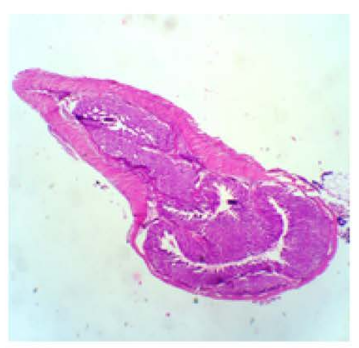

$\operatorname{Diet}(6) 4.0(\times 10)$

Figure 3. Light photomicrograph of intestine sections $(\mathrm{H}$ \&E) sea bass (Dicentrarchus labrax L) fed on diets supplemented with chitosan, showing normal villus structure in intestine in all treatments.

\section{Discussion}

The weaning period is one of the most stressful phases after newly fish hatching and fry development inducing digestive disorder, intestinal barrier dyes functions and impaired performance [31]-[33]. An improvement in fish growth performance for economic purposes can be achieved by enhancing growth rate. One of the strategies to reduce weanling stress is to provide a specific feed additive, such as chitosan. In the current study, chitosan was effective in increasing weight gain of weaned sea bass, which was in agreement with established literature [20]-[23].

Growth in sea bass is regulated in large part by the brain neuroendocrine GH-IGFs axis [34]. GH can influence skeletal and muscle growth via direct and indirect effects on protein, lipid and carbohydrate metabolism [35] and fulfill its function of growth promotion through improving the production of IGF-I. IGF-I can stimulate amino acid uptake and protein synthesis in muscles and can greatly reduce the rate of protein breakdown within muscle fibers [36]. The causes of this result are unclear and require further experimentation to solve.

The small intestine is the main place for digestion and absorption of nutrients, and the intestinal mucosa plays an important role in these processes. Weanling stress can result in relatively quick changes in the intestinal mucosa morphological structure, which lead to a reduction in villus height and an increase in crypt depth [37]. Abnormal intestinal morphological structure is usually associated with retarded growth of weanling sea bass fry. A shortening of the villus decreases the surface area for nutrient absorption, which leads to poor nutrient absorption and reduced performance [38]. In our study the villus length increased with increasing chitosan levels and 
reached maximum at concentration levels $1 \& 2 \mathrm{~g} \cdot \mathrm{kg}$ diet $^{-1}$ as shown in Table 5 and Figure 3 . The crypt is the area where stem cells divide to permit the renewal of the villus, and a large crypt indicates fast tissue turnover and a high demand for new tissue [39]. The ratio of villus height to crypt depth is a useful criterion for estimating the digestive capacity in the small intestine [40]. In agreement with the improved performance in sea bass, chitosan resulted in an improvement of intestinal morphological structure, as indicated by the increased small intestinal villus height and the ratio of villus height to crypt depth, and the decreased small intestinal crypt depth of sea bass in this study when fed on control and diet 2. Similar results were also reported by other investigators [41] [42]. It is well known that pathogenic germs such as coliforms can destroy the normal morphology of small intestinal mucosa. Our previous study indicated that dietary chitosan could inhibit the proliferation of $E$. coli in the intestine, and improve gut microecology [43]. Furthermore, chitosan provided a beneficial environment for the proliferation of enterocytes, preventing intestinal atrophy [42]. Those studies show that the application of chitosan in diets has promoted the health of epithelium as well as the micro villi of the gut indicated by a more complicated architectural gut structure with longer villi, and hence a large surface area for nutrient absorption.

From the results of this study, it can be concluded that chitosan supplementation in diets of sea bass is helpful in improving growth rate, and the improvement mechanism may be partly attributed to increased GH concentration in serum and ameliorated morphological structure of small intestine. The optimal response occurred at 1 $\mathrm{g} \cdot \mathrm{kg} \operatorname{diet}^{-1}$ chitosan.

\section{References}

[1] FAO (2012) The State of World Fisheries and Aquaculture Rome. 2014; p1-40.

[2] Crini, G. (2005) Recent Developments in Polysaccharide-Based Materials Used as Absorbents in Wastewater Treatment. Progress in Polymer Science, 30, 38-70. http://dx.doi.org/10.1016/j.progpolymsci.2004.11.002

[3] Huang, R.L., Yin, Y.L., Li, M.X., Wu, G.Y., Li, T.J., Li, L.L., Yang, C.B., Zhang, J., Wang, B.Z., Deng, Y., Zhang, Y.G., Tang, Z.R., Kang, P. and Guo, Y.M. (2007) Dietary Oligochitosan Supplementation Enhances Immune Status of Broilers. Journal Science of Food Agriculture, 87, 153-159. http://dx.doi.org/10.1002/jsfa.2694

[4] Li, H.Y., Yan, S.M., Shi, B.L. and Guo, X.Y. (2009) Effect of Chitosan on Nitric Oxide Content and Inducible Nitric Oxide Synthase Activity in Serum and Expression of Inducible Nitric Oxide Synthase mRNA in Small Intestine of Broiler Chickens. Asian-Aust. Journal Animal Science, 22, 1048-1053.

[5] Knaul, J.Z., Hudson, S.M. and Creber, K.A.M. (1999) Cross Linking of Chitosan Fibers with Dialdehydes: Proposal of a New Reaction Mechanism. Journal of Polymer Science Part B, Polymer Physics, 37, 1079-1094. http://dx.doi.org/10.1002/(SICI)1099-0488(19990601)37:11<1079::AID-POLB4>3.0.CO;2-O

[6] Wang, S.Q. and Zhang, C.S. (2004) Chitin, Chitosan and Their Applications in Aquaculture. Feed Res, 5, 25-28.

[7] Xu, C.L. and. Wang, Y.Z. (2005) The Applications of Chitin in Aquaculture. China Feed, 7, 30-32.

[8] Goiri, I., Oregui, L.M. and Garcia-Rodriguez, A. (2010) Use of Chitosan to Modulate Ruminal Fermentation of a 50:50 Forage-to-Concentrate Diet in Sheep. J. Anim. Sci, 88, 749-755. http://dx.doi.org/10.2527/jas.2009-2377

[9] Liao, F.H., Shieh, M.J., Chang, N.C and Chien. Y.W. (2007) Chitosan Supplementation Lowers Serum Lipids and Maintains Normal Calcium, Magnesium, and Iron Status in Hyperlipidemic Patients. Nutrition Research, 27, $146-151$. http://dx.doi.org/10.1016/j.nutres.2007.01.009

[10] Pusateri, A.E., Holcomb, J.B., Kheirabadi, B.S., Alam, H.B.; Wade, C.E. and Ryan, K.L. (2006) Making Sense of the Preclinical Literature on Advanced Hemostatic Products. J. Trauma-Injury Infection and Critical Care, 60, 674-682. http://dx.doi.org/10.1097/01.ta.0000196672.47783.fd

[11] Dai, T., Tegos, G.P., Burkatovskaya, M., Castano, A.P. and. Hamblin, M.R. (2009) Chitosan Acetate Bandage as a topical Antimicrobial Dressing for Infected Burns. Antimicrob. Agents Chemother, 53, 393-400. http://dx.doi.org/10.1128/AAC.00760-08

[12] Tsukada, K., Matsumoto, T., Aizawa, K., Tokoro, A., Naruse, R., Suzuki, S. and Suzuki, M. (1990) Antimetastatic and Growth-Inhibitory Effects of N-Acetylchitohexaose in Mice Bearing Lewis Lung Carcinoma. Japanese Journal Cancer Research, 81, 259-265. http://dx.doi.org/10.1111/j.1349-7006.1990.tb02559.x

[13] Koide, S.S. (1998) Chitin-Chitosan: Properties, Benefits and Risks. Nutrition Research, 18, 1091-1101. http://dx.doi.org/10.1016/S0271-5317(98)00091-8

[14] Limam, Z., Selmi, S., Sadok, S. and El-abed, A. (2011) Extraction and Characterization of Chitin and Chitosan from Crustacean By-Products: Biological and Physicochemical Properties. African Journal Biotechnology, 10, 640-647.

[15] Benhabiles, M.S., Salah, R., Lounici, H., Drouiche, N., Goosen, M.F.A. and Mameri, N. (2012) Antibacterial Activity 
of Chitin, Chitosan and Its Oligomers Prepared from Shrimp Shell Waste. Food Hydrocoll, 29, 48-56. http://dx.doi.org/10.1016/j.foodhyd.2012.02.013

[16] Yao, H.T., Huang, S.Y. and Chiang, M.T. (2006) Effect of Chitosan on Plasma Cholesterol and Glucose Concentration in Streptozotocin-Induced Diabetic Rats. Taiwan. J. Agric. Chem. Food Sci, 44, 122-132.

[17] Yao, H.T., Huang, S.Y and Chiang, M.T. (2008) A Comparative Study on Hypoglycemic and Hypocholesterolemic Effects of High and Low Molecular Weight Chitosan in Streptozotocin-Induced Diabetic Rats. Food Chemistry, Toxicology, 46, 1525-1534. http://dx.doi.org/10.1016/j.fct.2007.12.012

[18] Moon, J.S., Kim, H.K., Koo, H.C., Joo, Y.S., Nam, H.M., Park, Y.H. and Kang, M.I. (2007) The Antibacterial and Immunostimulative Effect of Chitosan-Oligosaccharides against Infection by Staphylococcus aureus Isolated from Bovine Mastitis. Appl. Microbiol. Biotechnol, 75, 989-998. http://dx.doi.org/10.1007/s00253-007-0898-8

[19] Yin, Y.L., Tang, Z.R., Sun, Z.H., Liu, Z.Q., Li, T.J., Huang, R.L., Ruan, Z., Deng, Z.Y., Gao, B., Chen, L.X., Wu, G.Y. and Kim. S. (2008) Effect of Galacto-Mannan-Oligosaccharides or Chitosan Supplementation on Cytoimmunity and Humoral Immunity Response in Early-Weaned Piglets. Asian-Aust. Journal Animal Science, 21, 723-731.

[20] Huang, R.L., Yin, Y.L., Wu, G.Y., Zhang, Y.G., Li, T.J., Li, L.L., Li, M.X., Tang, Z.R., Zhang, J., Wang, B., He, J.H. and Nie, X.Z. (2005) Effect of Dietary Oligochitosan Supplementation on Ileal Digestibility of Nutrients and Performance in Broilers. Poultry Science, 84, 1383-1388. http://dx.doi.org/10.1093/ps/84.9.1383

[21] Shi, B.L., Li, D.F., Piao, X.S. and Yan, S.M. (2005) Effects of Chitosan on Growth Performance and Energy and Protein Utilization in Broiler Chickens. British Poultry Science, 46, 516-519. http://dx.doi.org/10.1080/00071660500190785

[22] Khambualai, O., Yamauchi, K., Tangtaweewipat, S. and Cheva-Isarakul, B. (2009) Growth Performance and Intestinal Histology in Broiler Chickens Fed with Dietary Chitosan. British Poultry Science, 50, 592-597. http://dx.doi.org/10.1080/00071660903247182

[23] Yuan, S.B. and Chen, H. (2012) Effects of Dietary Supplementation Of chitosan on Growth Performance and Immune Index in Ducks. African Journal of Biotechnology, 11, 3490-3495.

[24] Horwitz, W. (2006) Official Methods of Analysis. 18th Edition, AOAC (Association of Official Analytical Chemists), Washington DC, 1018.

[25] Carson, F. (1992) Histotechnology: A Self-Instructional Text. ASCP Press, 19.

[26] Holden, M.J. and Raitt, D.F.S., Eds., (1975) Manual de ciencia pesquera. parte 2. Métodos para investigar los recursos y su aplicación. Doc Tec FAO Pesca, 115, 211.

[27] Golterman, H.L., Clymo, R.S. and Ohnstad, M.A.M. (1978) Methods of Physical and Chemical Analysis of Fresh Waters. Blackwell Scientific Publications, Oxford, 214 p.

[28] Cho, C.Y. and Kaushik, S.J. (1985) Effect of Protein Intake on Metabolizable and Net Energy Values of Fish Diets. In: Cowey, C.B., Mackie, A.M. and Bell, J.G., Eds., Nutrition and Feeding in Fish, Academic Press, London, 95-117.

[29] Statistical Analysis System (1993) SAS/STAT User’s Guide Release 6.03 edn. SAS Institute Inc., Cary.

[30] Zar, J.H. (1984) Biostatistician Analysis. Prentice Hall, Englewood Cliffs.

[31] Smith, F., Clark, J E., Overman, B.L., Tozel, C.C., Huang, J.H., Rivier, J.E., Blisklager, A.T. and Moeser, A.J. (2010) Early Weaning Stress Impairs Development of Mucosal Barrier Function in the Porcine Intestine. Am. J. Physiol. Gastrointest. Liver Physiology, 298, 352-363. http://dx.doi.org/10.1152/ajpgi.00081.2009

[32] Peace, R.M., Campbell, J., Polo, J., Crenshaw, J., Russell, L. and Moeser. A.J. (2011) Spray-Dried Porcine Plasma Influences Intestinal Barrier Function, Inflammation, and Diarrhea in Weaned Pigs. J. Nutrition, 141, 1312-1317. http://dx.doi.org/10.3945/jn.110.136796

[33] Kim, J.C., Hansen, C.F., Mullana, B.P. and Pluske, J.R. (2012) Nutrition and Pathology of Weaned Pigs: Nutritional Strategies to Support Barrier Function in the Gastrointestinal Tract. Animal Feed Science Technology, 173, 3-16. http://dx.doi.org/10.1016/j.anifeedsci.2011.12.022

[34] Eugene, T.W. and Russell, J.B. (2013) Endocrine Regulation of Compensatory Growth in Fish. Front Endocrinol (Lausanne), 4, 74-87.

[35] Pell, J.M. and Bates, P.C. (1990) The Nutritional Regulation of Growth Hormone Action. Nutrition Research Review, 3, 163-192. http://dx.doi.org/10.1079/NRR19900011

[36] Canosa, L.F., Unniappan, S. and Peter, R.E. (2005) Periprandial Changes in Growth Hormone Release in Goldfish: Role of Somatostatin, Ghrelin, and Gastrin-Releasing Peptide. American Journal of Physiology: Regulatory, Integrative and Comparative Physiology, 289, 125-13310. http://dx.doi.org/10.1152/ajpregu.00759.2004

[37] Baeverfjord, G. and Krogdahl, A. (1996) Development and Regression of Soybean Meal Induced Enteritis in Atlantic Salmon, Salmo salar L., Distal Intestine: A Comparison with the Intestines of Fasted Fish. Journal of Fish Diseases, 


\section{9, 375-387. http://dx.doi.org/10.1111/j.1365-2761.1996.tb00376.x}

[38] Xu, Z.R., Hu, C.H., Xia, M.S., Zhan, X.A. and Wang, M.Q. (2003) Effects of Dietary Fructooligos Accharide on Digestive Enzyme Activities, Intestinal Microflora and Morphology of Male Broilers. Poultry Science, 82, 1030-1036. http://dx.doi.org/10.1093/ps/82.6.1030

[39] Hu, C.H., Gu, L.Y., Luan, Z.S., Song, J. and Zhu, K. (2012) Effects of Montmorillonite-Zinc Oxide Hybrid on Performance, Diarrhea, Intestinal Permeability and Morphology of Weanling Pigs. Animal Feed Science Technology, 177, 108-115. http://dx.doi.org/10.1016/j.anifeedsci.2012.07.028

[40] Montagne, L., Pluske, J.R. and Hampson, D.J. (2003) A Review of Interactions between Dietary Fibre and the Intestinal Mucosa, and Their Consequences on Digestive Health in Young Non-Ruminant Animals. Animal Feed Science Technology, 108, 95-117. http://dx.doi.org/10.1016/S0377-8401(03)00163-9

[41] Torzsas, T.L., Kendall, C.W., Sugano, M., Iwamoto, Y. and Rao, A.V. (1996) The Influence of High and Low Molecular Weight Chitosan on Colonic Cell Proliferation and Aberrant Crypt Foci Development in CF1 Mice. Food Chemistry and Toxicology, 34, 73-77. http://dx.doi.org/10.1016/0278-6915(95)00083-6

[42] Han, X.Y., Du, W.L., Huang, Q.C., Xu, Z.R. and Wang, Y.Z. (2012) Changes in Small Intestinal Morphology and Digestive Enzyme Activity with Oral Administration of Copper-Loaded Chitosan Nanoparticles in Rats. Biological Trace Elements Research, 145, 355-360. http://dx.doi.org/10.1007/s12011-011-9191-X

[43] Xu, Y.Q., Shi, B.L., Li, J.L., Li, T.Y., Guo, Y.W., Tian, L.X., Fu, X.Z. and Hong, L. (2012) Effects of Chitosan on Intestinal Flora in Weaned Pigs. Feed Res, 10, 54-56.

[44] Madan, M., Bhanja, S.K. and Yasmeen, B. (2009) Performance of Chitin Incorporated Diet on the Indigenous Kumaon Himalayan Fishes: Snow Trout, Schizothorax richardsonii (Gray) and Golden Mahseer, Tor putitora (Hamilton). Indian J. Fish., 56, 135-137.

[45] El-Saidy, D.M.S. and Gaber, M.M. (1998) Evaluation of the Nutritional Effects of Using Different Levels of Molasses in Prepared Practical Diets for Nile Tilapia Oreochromis niloticus L Fry. Menofiya Journal of Agriculture Research, 23, 591-602 